(c) American Dairy Science Association, 2005.

\title{
Changes in Feeding, Drinking, and Standing Behavior of Dairy Cows During the Transition Period
}

\author{
J. M. Huzzey, M. A. G. von Keyserlingk, and D. M. Weary \\ Animal Welfare Program, Faculty of Agricultural Sciences, The University of British Columbia, \\ Vancouver, British Columbia, V6T 1Z4, Canada
}

\begin{abstract}
The aims of this study were to determine how measures of feeding, drinking, and standing behavior change over the period around calving, to derive objective meal and drinking bout criteria for transition cows, and to describe the within-cow consistency of these behavioral measures. Fifteen transition dairy cows were monitored from $10 \mathrm{~d}$ before until $10 \mathrm{~d}$ after calving. Meal criteria were calculated for each cow in both the pre- and postcalving periods and varied among cows from 5.3 to $105.2 \mathrm{~min}$. There was a tendency for the average number of meals per day to be higher after calving than before calving, but time spent eating declined from 87 to $62 \mathrm{~min} / \mathrm{d}$ from the precalving to the postcalving period. Time spent drinking before calving averaged $5.5 \mathrm{~min} / \mathrm{d}$ and increased gradually after calving to an average of $6.8 \mathrm{~min} / \mathrm{d}$. Total daily standing times remained reasonably similar over the transition period but were highest at around calving $(14.4 \mathrm{~h})$ and lowest during the precalving period $(12.3 \mathrm{~h})$. On the day of calving, there was a dramatic increase in the number of standing bouts (21.8 bouts) compared with the pre- and postcalving averages of 11.7 and 13.1 bouts, respectively. In summary, changes in feeding behavior may help account for the well-documented changes in feed intake during transition. Documented changes in standing behavior suggest that cow comfort may be particularly important during the time around calving.
\end{abstract}

(Key words: transition, feeding behavior, drinking behavior, standing behavior)

\section{INTRODUCTION}

The transition phase, typically defined as 3 wk before to 3 wk after parturition (Grummer, 1995; Drackley, 1999), is viewed as a critical time in the lactation cycle of a dairy cow. During this period, the cow experiences

Received September 10, 2004.

Accepted March 29, 2005.

Corresponding author: Juliana Huzzey; e-mail: jmhuzzey@ interchange.ubc.ca. a series of nutritional, physiological, and social changes and is more vulnerable to infectious and metabolic diseases (Goff and Horst, 1997).

One of the major challenges faced by the cow at this time is obtaining sufficient energy to support the onset of lactation, especially given that feed intake tends to be suppressed around the time of calving (Drackley, 1999). A general decline in DMI beginning 3 wk before calving has been reported (Drackley, 1999), followed by a gradual increase in DMI in the weeks following calving (Osborne et al., 2002). Although changes in intake must be mediated by changes in feeding behavior, no research has examined the effects of transition on feeding behavior. Previous research on the effects of stage of lactation on changes in feeding behavior has been limited to cows in early to midlactation. DeVries et al. (2003b) reported that cows were highly consistent in some measures of feeding behavior such as daily feeding time. Moreover, feeding time increased when cows were 94 DIM compared with when they were 35 DIM.

Tolkamp and colleagues (Tolkamp et al., 1998, 2000; Yeates et al., 2001) argued that dairy cows divide their feeding time into a series of meals separated by nonfeeding intervals. In a model developed by these researchers and later adapted by DeVries et al. (2003b), the distribution of a large sample of intervals between visits to the feed alley was used to objectively define the meal criterion (i.e., the minimum interval between visits to consider the next visit to the feed alley as being part of a new meal). This model assumes that the frequency distribution of intervals between meals is affected by satiety, but the model has yet to be applied to the feeding behavior of transition cows that are experiencing dramatic changes in both diet and intake. Therefore, the first objective of this study was to apply the model described by Tolkamp et al. (1998) to feeding behavior of transition cows, to determine the within-cow consistency of meal criteria, meal number, and feeding time, and to determine how these measures change from preto postcalving.

Despite the importance of adequate water intake for both health and milk production, there has been very little research on drinking behavior in dairy cattle. Dado and Allen (1993) were the first to describe the 
drinking patterns of loose-housed cows, providing evidence that water intake is positively correlated with both DMI and the number of meals per day (Dado and Allen, 1994). The second objective of our study was to use mixed distribution models to define drinking bout criteria during the transition period. As with the measures of feeding behavior, we also tested if drinking bout criteria, drinking bout frequency, and total daily drinking time were consistent within cow and if they changed from pre- to postcalving.

Many authors have identified the importance of adequate resting times for dairy cattle (e.g., Arave and Walters, 1980; Haley et al., 2000; Overton et al., 2002). Disturbed rest and uncomfortable resting areas during transition may result in a physiological stress response (indicated by altered levels of plasma cortisol and increased heart rate in dairy cattle; Ladewig and Smidt, 1989; Müller et al., 1989), increasing the susceptibility to disease. To date, only one group of researchers (Dechamps et al., 1989) has examined the resting behavior of transition cows, and that study was in a tie-stall facility. Therefore, the final objective of the current study was to determine within-cow consistency and changes in standing behavior during the transition period.

\section{MATERIALS AND METHODS}

\section{Animals, Housing, and Diet}

Five primiparous and 10 multiparous (parity $=2.7 \pm$ $0.2)$ Holstein dairy cows were used in the current study. The animals were housed in a free-stall barn at The University of British Columbia Dairy Education and Research Center (Agassiz, British Columbia, Canada) and were cared for according to the guidelines outlined by the Canadian Council on Animal Care (1993). Each pen used in the study contained 12 stalls deep-bedded with sand, $7.2 \mathrm{~m}$ of linear feed bunk space fitted with a post-and-rail feed barrier, and 1 water trough (183 $\mathrm{cm}$ long, $41 \mathrm{~cm}$ wide, and $38 \mathrm{~cm}$ deep). Starting $21 \mathrm{~d}$ before calving, cows were fed a TMR consisting of $25.8 \%$ alfalfa hay, $47.9 \%$ corn silage, and $26.3 \%$ protein mineral supplement per cow on a DM basis (DM $41.1 \%$, CP $15.0 \%$, ADF $20.0 \%$, and NDF $33.5 \%$ ). After calving, cows were fed a TMR consisting of $15.6 \%$ corn, $7.2 \%$ grass hay, $1.8 \%$ alfalfa hay, $25.6 \%$ corn silage, $11.2 \%$ grass silage, and $38.6 \%$ protein mineral supplement per cow on a DM basis (DM $43.2 \%$, CP $17.5 \%$, ADF $16.6 \%$, and NDF $27.9 \%$ ). Fresh feed was provided twice daily at 0630 and $1630 \mathrm{~h}$. After calving, the cows were milked twice daily at approximately 0500 and $1500 \mathrm{~h}$.

\section{Experimental Design}

Close-up cows (animals up to 3 wk prepartum) were moved into an experimental pen of 12 cows approximately $14 \mathrm{~d}$ before their expected calving date. Due to differences between the predicted and the actual calving dates, our analysis began $10 \mathrm{~d}$ before calving to include a complete sample of cows for all observational days. Cows were moved to individual maternity pens approximately $1 \mathrm{~d}$ before calving until $1 \mathrm{~d}$ after calving and then moved into 1 of 2 groups of 12 fresh cows (animals up to $3 \mathrm{wk}$ postpartum) where they were monitored for an additional $10 \mathrm{~d}$. The stocking density in all of the observational pens remained constant at $1 \mathrm{cow}$ per stall.

\section{Feeding Behavior}

An electronic system (GrowSafe Systems Ltd., Airdrie, Alberta, Canada) was used to continuously monitor the presence of individual cows at the feed bunk in each experimental pen. This system has been previously described (DeVries et al., 2003b) and validated (DeVries et al., 2003a). Radio frequency transponders molded into plastic ear tags (Allflex USA, Dallas-Fort Worth Airport, TX) were fixed to the bottom of the neck collar of each cow. The system scanned for the presence of each animal's transponder at the feed bunk approximately once every $6 \mathrm{~s}$ (reader panels 1 and 2) or $3 \mathrm{~s}$ (reader panel 3). A "hit" was recorded if a transponder was recognized within $50 \mathrm{~cm}$ of the system. The number of daily hits recorded for each cow was determined using Matlab (The MathWorks Inc., Natick, MA), and these data were used to quantify the amount of time the animal spent at the feed bunk (i.e., number of hits $x$ $6 \mathrm{~s}$ or $3 \mathrm{~s}$ (depending on panel) $/ 60 \mathrm{~s}$ per $\min =\min$ feeding time).

\section{Drinking Behavior}

Drinking behavior was monitored in both the closeup and fresh pens using video cameras (CCTV camera, model WV-BP330, Panasonic, Osaka, Japan) with an F1.4/2.5-6 mm lens. These cameras were connected to a video multiplexer (Panasonic Video Multiplexer, WJFS 416) and a time-lapse videocassette recorder (Panasonic Time Lapse video cassette recorder, AG-6540). The 3 cameras were placed in the same position $7.6 \mathrm{~m}$ above the water trough of each pen. Red lights (100 W), hung adjacent to the cameras, were used to facilitate video recording at night. Cows were identified using unique alphanumeric symbols made with hair dye. Video recordings were analyzed by continuous observation on precalving $d-9 \pm 1,-6 \pm 1$, and $-4,-3,-2$, and -1 , and postcalving $\mathrm{d}+1,+2,+3,+4,+6 \pm 1$, and $+9 \pm$ 
1. A cow was scored as drinking when its muzzle or tongue was in contact with the water. To determine the interobserver reliability of this measure, 2 trained observers scored the same tapes independently. Estimates of drinking time from these observations were highly correlated (Pearson $r=0.98$ ).

\section{Standing Behavior}

Because a standing event is usually not interrupted by short lying events, a standing bout is defined as the interval between 2 lying events. We used a modified data logger (Gemini Dataloggers Ltd., Chichester, UK) to quantify the number of standing bouts, as well as the total time spent standing and lying per day. This data logger uses a mercury switch to determine leg orientation (standing vs. lying) and was programmed to record position every $2.5 \mathrm{~min}$. The device was placed into a fabric pouch and attached to either hind leg of each cow with vet-wrap (CoFlex, Andover Coated Products Inc., Salisbury, MA). The data logger was removed for approximately 5 min during the afternoon milking every 4 to $5 \mathrm{~d}$ to download data.

\section{Data Analysis}

Meal and bout criteria were established from the feeding and drinking data using mixed distribution models. Individual feeding meal and drinking bout criteria were calculated for each cow for each period and a combined feeding criterion and drinking criterion was calculated using the intervals from all cows for all periods. The criteria were calculated using the frequency distribution of the $\log _{10}$-transformed intervals between hits, based on the methods described by DeVries et al. (2003b). The scanning interval used by the GrowSafe system resulted in a natural periodicity of hit intervals at $6 \mathrm{~s}$ or $3 \mathrm{~s}$, depending on which panel was being used. On a $\log _{10}$ scale these were most evident at $6,9,12,15$, 18 , and $24 \mathrm{~s}$, so intervals less than $25 \mathrm{~s}$ were removed before the analysis of the feeding meal criterion. Criteria for meals and drinking bouts were calculated using the same methods and software (MIX 3.1.3) as described by DeVries et al. (2003b). Each criterion was determined to be the point where the distribution curve of the intrameal intervals (first distribution) intersected the distribution curve of the intermeal intervals (second distribution). The calculated criteria for feeding meals and drinking bouts were used to determine daily estimates of meal/bout frequency per cow (meals per day and bouts per day, respectively); this was done by counting the number of intervals per day that exceeded the criterion and then adding 1 to this value (i.e., if 7 intervals exceed the criterion, then the number of meals for that day would be $7+1=8$ meals per day). To determine if the use of a combined criterion is appropriate for future calculations of meal based measures, we regressed the daily estimates of meal frequency (meals/cow per d) calculated using the individual criteria onto the daily estimates of meal frequency (meals/ cow per d) calculated using the combined criteria.

For all analyses, the cow was considered the observational unit. The measures were summarized for each day, and then summarized by observational periods. The periods before and after calving ( $d-10$ to $d-2$ vs. $\mathrm{d}+2$ to $\mathrm{d}+10$ ) were considered separately. On those days when cows were in the calving pen $(d-1$ to +1$)$, feeding and drinking data were not recorded. The data loggers used to measure standing time were attached throughout, so we were able to collect standing data for these $3 \mathrm{~d}$ around calving (calving period). The analysis of daily feeding time and lying behavior was based on only 12 of the original 15 cows due to malfunctioning transponders and data loggers. The 3 cows removed from the feeding analyses were primiparous, whereas the 3 cows removed from the standing analyses were multiparous. An additional 2 cows (multiparous) were removed from the analysis of meal criterion and meal frequency, as intervals between feeding events were not available for these animals due to technical difficulties. Period means were compared using paired $t$-tests. In addition, we used linear regression to determine the within cow consistency of behaviors across the pre- and postcalving periods, and tested both if the intercept was different from zero and if the slope was different from 1 to determine if behavior changed across periods and how this varied depending upon the cow's starting point.

\section{RESULTS}

\section{Feeding Behavior}

Meal criteria were calculated separately for each cow for each period and varied among cows from 5.3 to 105.2 $\mathrm{min}$. The combined criterion for both the pre- and postcalving period was $26.4 \mathrm{~min}$. There was a significant relationship between meal frequency estimates (preand postcalving) calculated with individual and combined meal criteria $\left(\mathrm{R}^{2}>0.59, P<0.001\right)$. However, estimates of meal frequency using the individual criteria were consistently higher during the postcalving period than the estimates obtained using the combined criterion, as reflected by the positive intercept term $(1.56 \pm 0.52, P=0.004$, Figure 1A). During the precalving period, the estimates of slope and intercept were not different from 1 and 0 , respectively $(P>0.1)$. Based on the differences found for the postcalving period, all subsequent meal-based analyses were based on individ- 

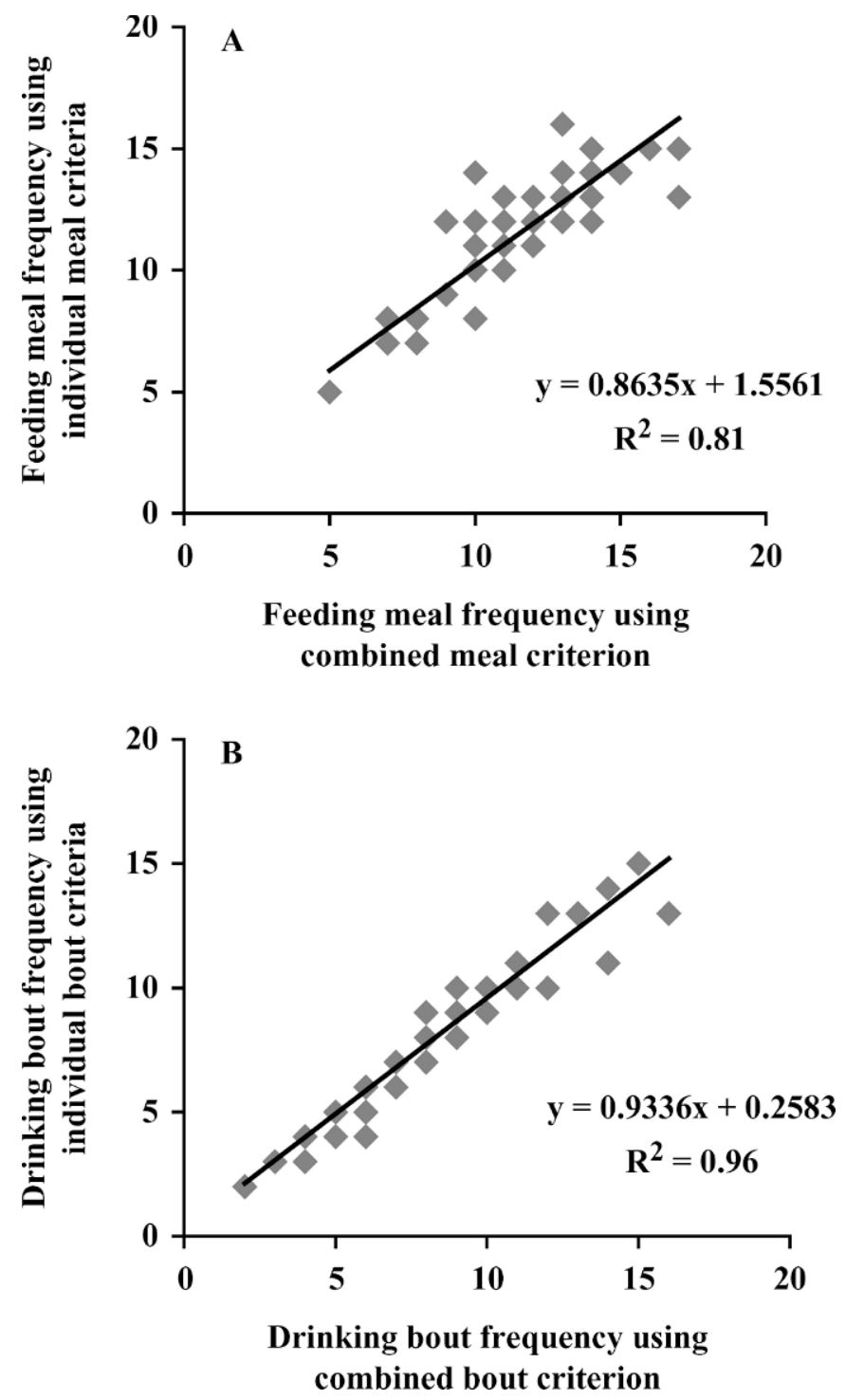

Figure 1. The relationship of (A) feeding meal frequency (meals/ cow per d) calculated with a combined meal criterion (26.4 min) and with individual criteria for the postcalving period; and the relationship of (B) drinking bout frequency (bouts/cow per d) calculated with a combined bout criterion (5.27 $\mathrm{min})$ and with individual criteria for the precalving period.

ual meal criteria to provide the most accurate estimate of meal frequency. Figure 2A is a representative example of the frequency distribution of the intervals between feeding events, along with the fit of the model, used to determine the feeding meal criterion for 1 of the cows in this study. The average meal criterion was $34.7 \pm 8.01 \mathrm{~min}$ in the precalving period and $24.7 \pm 2.84$ min in the postcalving period. There was a tendency for the average number meals per day to be lower before calving than after calving $(9.8 \pm 0.48$ vs. $11.1 \pm 0.48$ meals/d respectively; $P=0.09$; Figure $3 \mathrm{~A}$ ). Upon re-
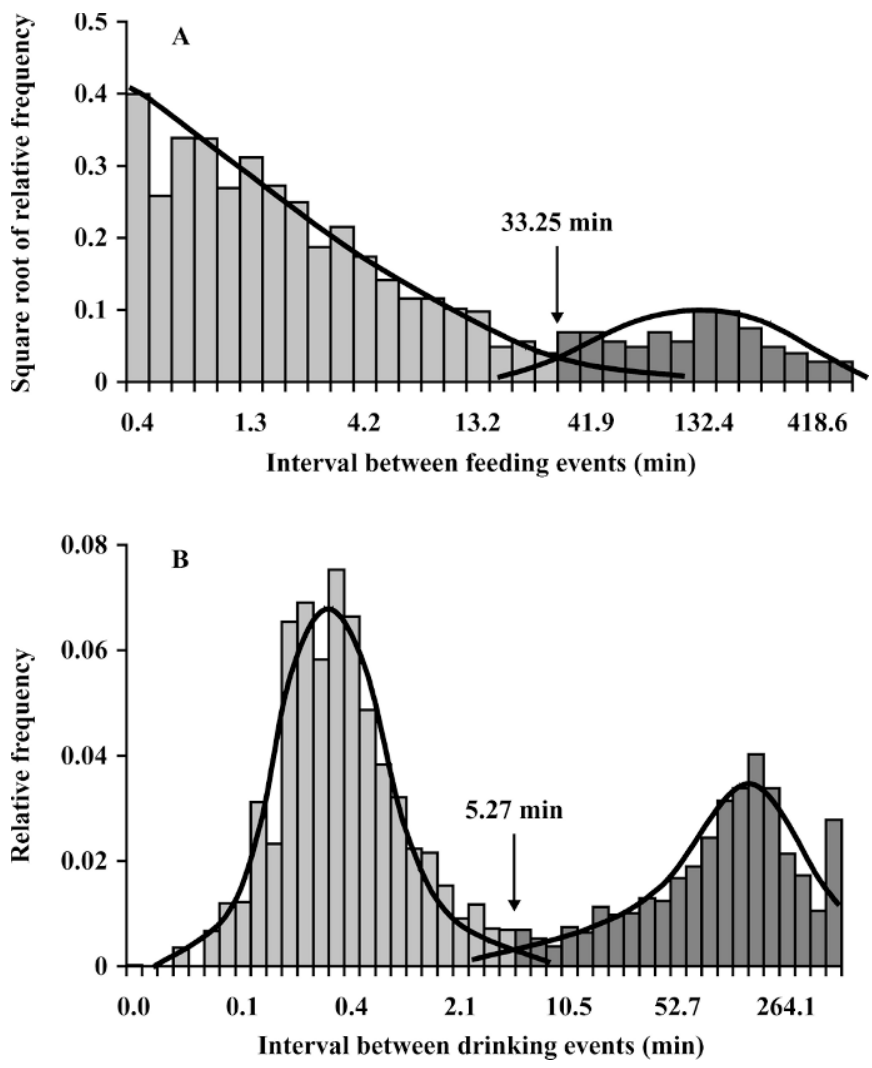

Figure 2. (A) The square-root transformed relative frequency distribution (\% total observations) of the intervals between feeding events for Cow 15 during the postcalving period $(n=1255)$. The square root transformation was used to better illustrate the 2 distributions, but was not used in the mixture analysis of the distributions. (B) The relative frequency distribution of the intervals between drinking events $(n=4171)$. The mixed distribution model fit distributions and the meal/bout criteria were determined to be the point where the 2 distributions crossed.

gressing the meal frequency precalving against meal frequency postcalving, we found a significant relationship $\left(\mathrm{R}^{2}=0.41 ; P=0.05\right)$. For this regression, the intercept was significantly higher than zero $(7.01 \pm 1.78, P=$ $0.004)$ and the slope was significantly $<1(0.42 \pm 0.18$, $P=0.01$, illustrating that cows with lower meal numbers before calving showed greater increases after calving.

The daily time spent feeding was variable over the precalving period, but averaged $86.8 \pm 2.95 \mathrm{~min} / \mathrm{d}$ (Figure $3 \mathrm{~B}$ ). During the postcalving period, the daily time spent feeding was lower (on average $61.7 \pm 2.95 \mathrm{~min} /$ d; $P<0.001$ ) compared with the precalving period, but increased by approximately $3.3 \mathrm{~min} / \mathrm{d}$. Regression analysis determined that there was little consistency in the feeding times within cow between the pre- and postcalving period $\left(\mathrm{R}^{2}=0.17, P=0.2\right)$. 

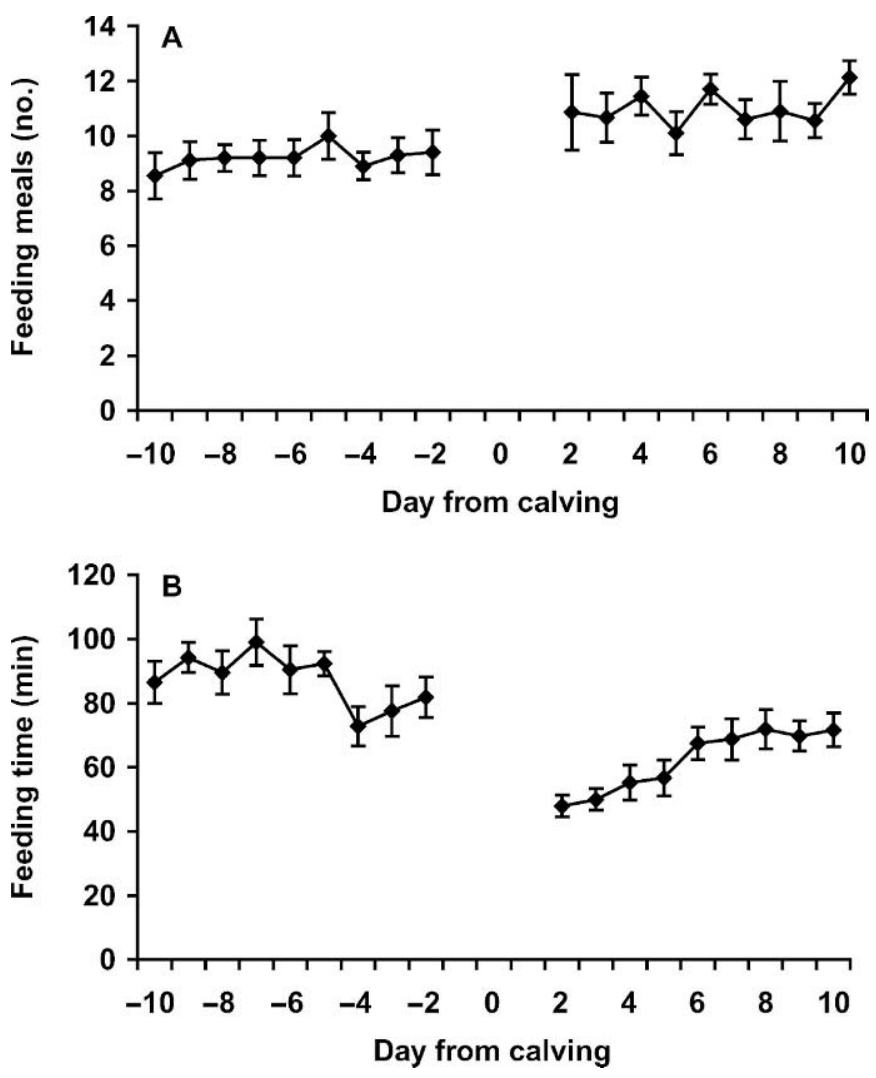

Figure 3. Changes in mean $( \pm \mathrm{SE})$ number of daily meals $(\mathrm{n}=$ 10 cows) (A) and daily feeding time ( $\mathrm{n}=12$ cows) (B) during the transition period.

\section{Drinking Behavior}

Drinking bout criteria were calculated separately for each cow for each period, and varied among cows from 1.3 to $33.3 \mathrm{~min}$. The use of a combined criterion (5.3 $\mathrm{min}$ ) vs. the individual criterion resulted in very similar estimates of bout frequency for each cow. The relationship between the combined and individual estimates for the precalving period is shown in Figure 1B, and a very similar relationship was found for the postcalving period $\left(\mathrm{R}^{2}=0.92 ; P<0.001\right)$. In both periods, the intercept did not differ from zero and the slope did not differ from $1(P>0.1)$. We therefore used the combined drinking bout criterion for the subsequent analysis of bout frequency. Figure 2B shows the frequency distribution of the intervals between drinking events, along with the fit of the model used to determine this bout criterion. The average number of drinking bouts during the precalving period was $6.6 \pm 0.4 \mathrm{bouts} / \mathrm{d}$, increasing to an average of $9.5 \pm 0.4$ bouts/d during the postcalving pe$\operatorname{riod}(P<0.001$, Figure $4 \mathrm{~A})$. Regression analysis showed consistency in the frequency of drinking bouts/d in prevs. postcalving periods $\left(\mathrm{R}^{2}=0.38 ; P=0.01\right)$. In this
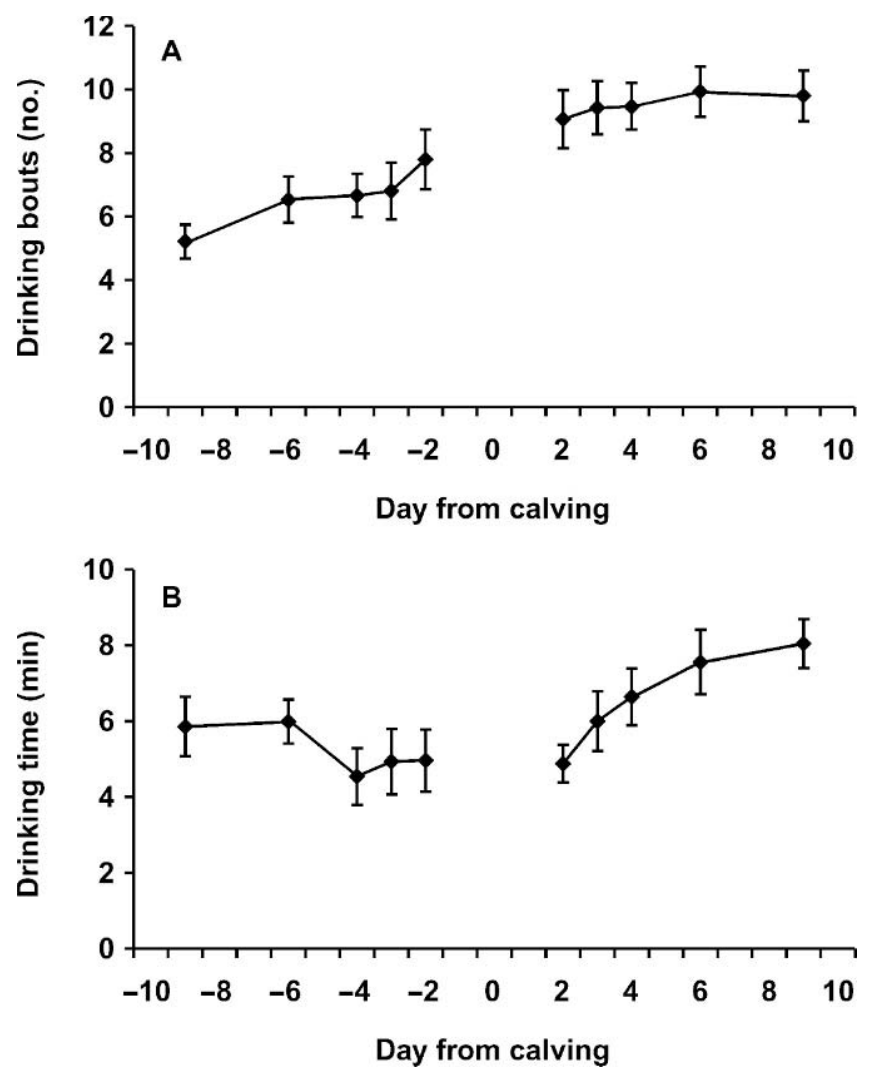

Figure 4. Changes in mean $( \pm \mathrm{SE})$ number of daily drinking bouts (A) and daily drinking time (B) during the transition period ( $\mathrm{n}=$ 15 cows).

case, the intercept term was positive $(5.35 \pm 1.55 ; P=$ $0.004)$ illustrating a general increase from pre- to postcalving, and the slope did not differ from $1(0.63 \pm 0.22$; $P=0.12$ ), indicating that the increase was similar across cows.

The time spent drinking before calving averaged 5.5 $\pm 0.29 \mathrm{~min} / \mathrm{d}$, and declined only slightly over this period (Figure 4B). Drinking times then increased steadily after calving at a rate of approximately $0.4 \mathrm{~min} / \mathrm{d}$, resulting in a higher average drinking time during the postcalving period $(6.8 \pm 0.29 \mathrm{~min} / \mathrm{d} ; P=0.013)$. As with meal frequency, cows were reasonably consistent in drinking times before and after calving $\left(\mathrm{R}^{2}=0.44 ; P=\right.$ 0.007). However, in this case, cows showed similar increases in drinking time as evidenced by the intercept being greater then zero $(2.92 \pm 1.27 ; P=0.04)$ and the slope being close to $1(0.70 \pm 0.22 ; P=0.2)$.

\section{Standing Behavior}

Total daily standing times remained reasonably constant over the transition period (Figure 5A). The average standing time per day during the precalving period 

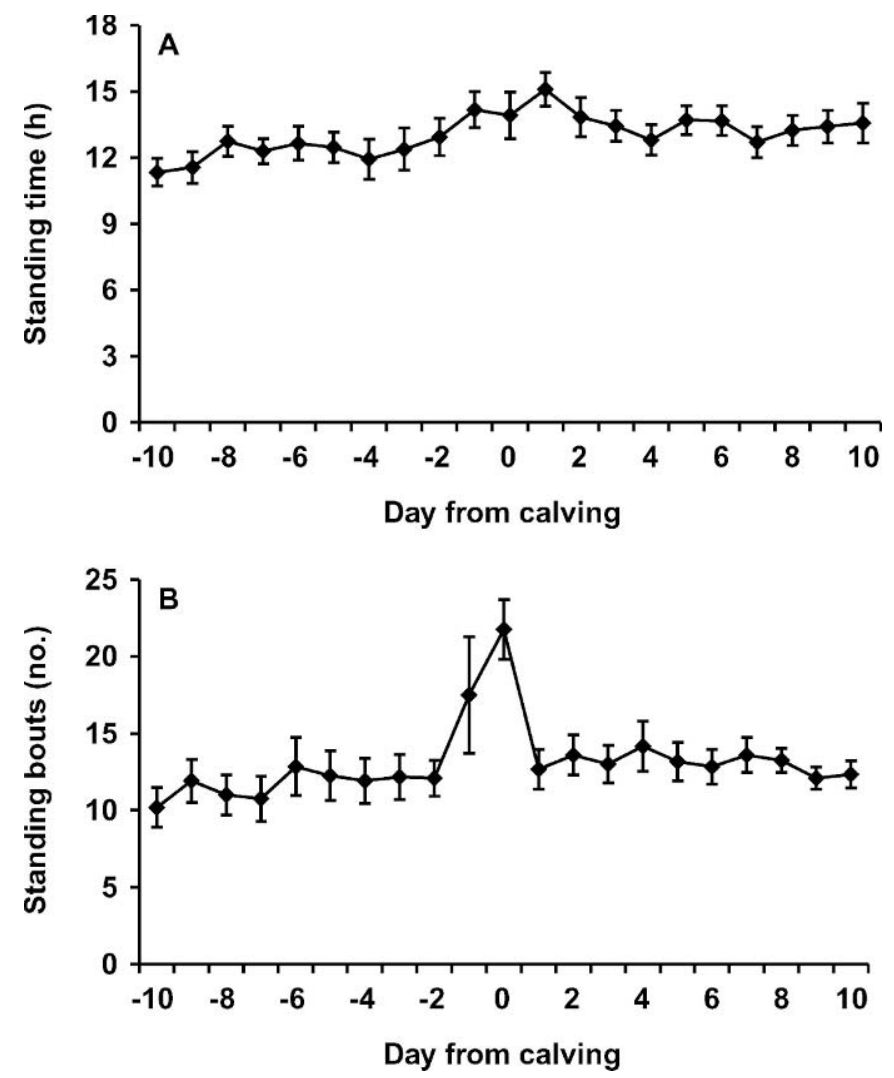

Figure 5. Changes in mean $( \pm \mathrm{SE})$ daily standing time $(\mathrm{A})$ and number of daily standing bouts $(\mathrm{B})$ during the transition period $(\mathrm{n}=$ 12 cows).

was $12.3 \pm 0.3 \mathrm{~h} / \mathrm{d}$, and this value increased only slightly for the postcalving period $(13.4 \pm 0.3 \mathrm{~h} / \mathrm{d} ; P=0.02)$. However, standing times were notably higher during the calving period ( $d-1$ to $d+1 ; 14.39 \pm 0.29 \mathrm{~h} / \mathrm{d}$ ) compared with both pre- and postcalving periods $(P<0.001)$. Cows were reasonably consistent in their standing times across the pre- and postcalving periods $\left(R^{2}=0.73\right.$; $P<0.001$ ), and for this regression, the intercept tended to be slightly higher than zero $(3.81 \pm 1.87 ; P=0.07)$ and the slope not different from $1(0.78 \pm 0.15 ; P=0.2)$.

There was no significant difference in the number of standing bouts during the precalving and the postcalving periods $(11.7 \pm 1.07$ and $13.1 \pm 1.07 \mathrm{bouts} / \mathrm{d}$ respectively; $P>0.3$; Figure 5B). Moreover, regression analysis determined that there was little consistency in the number of standing bouts within cow between these 2 periods $\left(\mathrm{R}^{2}=0.20, P>0.1\right)$. However, the average number of standing bouts during the calving period was significantly higher $(17.3 \pm 1.08$ bouts $/ \mathrm{d} ; P=0.002$, Figure $5 \mathrm{~B}$ ) than during the pre- and postcalving periods.

\section{DISCUSSION}

\section{Feeding Behavior}

Establishing a meal criterion allows us to summarize feeding behavior data by calculating meal frequency. The individual meal criteria calculated for the transition cows used in this study were much more variable than those previously reported by DeVries et al. (2003b) and Tolkamp et al. (1998), who based their work on cows further into lactation (35 to $94 \mathrm{DIM}$ and 60 to 210 DIM, respectively). The known variation between animals in DMI (Drackley, 1999) and the dramatic physiological changes associated with transition likely contributed to large between-cow variation in meal criteria. Another possible contributor to the variation in estimates of meal criteria may be the low number of observations (intervals between feeding events) per cow.

Meal frequency increased from precalving to postcalving, perhaps due to an increase in competitive interactions when moving animals into a new group of lactating cows after calving. Olofsson (1999) showed that frequency of visits to the feeder increased with increasing competition. The increased energy demands resulting from lactation may also have been a factor. Increased DMI may be achieved through increased meal number, meal duration, or eating rate (Nielsen, 1999).

In the present study, cows were not consistent in their daily feeding times across the pre- and postcalving periods but were more consistent in meal frequency. Thus, measures of meal frequency may be more sensitive than other measures of feeding behavior for monitoring feeding during transition. These findings are in contrast with earlier work on lactating cows (DeVries et al., 2003b), showing that meals were a relatively insensitive measure compared with total daily feeding time.

We found that cows spent less time at the feed bunk in the postcalving period compared with the precalving period. Consistent with common transition cow management practice, cows in this study were switched to a higher energy diet immediately after calving. This was achieved by increasing the concentrate portion of the diet, a practice that has previously been shown to increase feeding rate in dairy cattle (Friggens et al., 1998). Osborne et al. (2002) also reported similar values of DMI for the week before and the week after calving, despite differences in energy density in the respective diets. Although DMI was not determined in the current study, these previous studies suggest that the decreased feeding times postcalving may be explained by an increased feeding rate compared with the precalving period. Rapid changes in diet can alter the microbial environment of the rumen. Specifically, increases in 
concentrate intake can lower the ruminal $\mathrm{pH}$, increasing the risk of subclinical ruminal acidosis (NRC, 2001). Cows in the transition phase are susceptible to subclinical acidosis, and the presence of this disorder could result in a reduction in feed intake (Nocek, 1997). In the present study, feeding times may have been depressed for this reason and we encourage future research in this area.

\section{Drinking Behavior}

Water is considered the most important nutrient for the lactating cow (NRC, 2001), but little research has focused on drinking behavior. Similar to the challenges of defining the criteria used to separate feeding events into meals, research on drinking events requires an objective method of defining a bout criterion to derive measures such as number of daily drinking bouts. Dado and Allen (1993) defined the drinking bout criterion to be 4 min using a log-survivorship curve. Their approach at modeling the drinking bout criterion assumes that the probability of the start of a drinking event is independent of the time since the last event. However, modeling the frequency distribution of intervals between drinking events is likely a more biologically appropriate method of estimating bout criteria for ingestive behaviors (Tolkamp et al., 1998; Yeates et al., 2001; DeVries et al., 2003b). Recent work on drinking patterns of Swedish Red and White dairy cows (Melin et al., 2005) applied a mixed distribution model to objectively cluster a series of drinking events into bouts separated by a 3.7-min bout criterion.

Our study is the first to model drinking events during transition. Although there was variation between cows in drinking bout criteria, use of a combined criterion $(5.3 \mathrm{~min})$ resulted in very similar estimates of bout frequency. This combined criterion was slightly higher than that previously reported by Dado and Allen (1993) and Melin et al. (2005), perhaps due to differences in stage of lactation, type of housing, or water delivery systems.

The increase in the number of drinking bouts and the $20 \%$ increase in total daily drinking time postcalving compared with precalving may be explained by the increased water requirements due to lactation (NRC, 2001). Osborne et al. (2002) found that water intake increased from $57 \mathrm{~L} / \mathrm{d}$ during the week before calving to $73 \mathrm{~L} / \mathrm{d}$ during the week after calving.

Our estimate for the number of drinking bouts after calving is lower than that reported by both Dado and Allen (1994) and Melin et al. (2005). To determine if this was due to our use of a longer drinking bout criterion, we compared the frequency of drinking bouts obtained when using the 4-min criterion reported by Dado and Allen (1993) to the frequency of drinking bouts obtained using our criterion (5.3 min). Although, in both the pre- and postcalving period, the use of the longer criterion resulted in slightly lower estimates of bout frequency, regression analysis showed no difference between the estimates. The lower frequency of drinking bouts observed during the postcalving period in our study may be due to differences in stage of lactation rather than differences in bout criterion. Cows in the present study were in their first week of lactation and likely were not consuming as much water as the cows used in previous studies that were closer to peak lactation.

\section{Standing Behavior}

The increased standing time after calving was not surprising given that the lactating cows must spend time (standing) in the parlor. During the calving period, daily standing times were $2 \mathrm{~h}$ longer than during the precalving period and $1 \mathrm{~h}$ longer than during the postcalving period, perhaps reflecting increased activity around the calving event.

The pre- and postcalving standing times recorded in our study (12.3 and $13.4 \mathrm{~h} / \mathrm{d}$, respectively) are the first to be reported for freestall-housed transition cows. Dechamps et al. (1989) reported a similar average standing time $(12.4 \mathrm{~h} / \mathrm{d})$ for transition cows housed in tiestalls. Our results are also similar to those of other researchers (Konggaard, 1983; Krohn and Munksgaard, 1993) who reported standing or lying times for loose-housed cows during other stages of lactation, suggesting that standing times are only increased immediately around the time of calving.

The $80 \%$ increase in the number of standing bouts during the calving period suggests that cows were more restless, likely due to the discomfort associated with calving. This result also suggests that special attention should be placed on cow comfort in the maternity pen, particularly to aspects of stall surface known to affect comfort when changing positions (Tucker and Weary, 2004). To our knowledge, our study is the first to describe changes in standing behavior at calving although increased restlessness as parturition approaches has been commonly observed.

\section{CONCLUSIONS}

Criteria for feeding meals and drinking bouts can be objectively determined for transition cows and used to derive meal number and number of drinking bouts. Our results indicate that meal frequency is more sensitive than feeding time as a measure of feeding behavior during the transition period. Meal and drinking bout 
frequency and total drinking time increased when cows moved from the pre- to the postcalving period, likely reflecting the changes in feed and water intake that occur during transition.

\section{ACKNOWLEDGMENTS}

We would like to thank the staff of The University of British Columbia's Dairy Education and Research Centre and the University's Animal Welfare Program. We are grateful to Trevor DeVries for his help with the analysis and his commenting on earlier drafts of this manuscript. We also thank Geoff Urton for collecting the feeding behavior data and Christoph Winckler for his advice during the early stages of this work. Juliana Huzzey was supported in part by a Natural Sciences Engineering Research Council of Canada (NSERC) Undergraduate Summer Research Scholarship. This project was funded by the Agriculture and Agri-Food Canada/NSERC Research Partnership Support Program made possible by contributions from the Dairy Farmers of Canada.

\section{REFERENCES}

Arave, C. W., and J. L. Walters. 1980. Factors affecting lying behavior and stall utilization of dairy cattle. Appl. Anim. Ethol. 6:369-376.

Canadian Council on Animal Care. 1993. Guide to the Care and Use of Experimental Animals. Vol. 1. E. D. Olfert, B. M. Cross, and A. A. McWilliam, ed. CCAC, Ottawa, Ontario, Canada.

Dado, R. G., and M. S. Allen. 1993. Continuous computer acquisition of feed and water intakes, chewing, reticular motility, and ruminal pH of cattle. J. Dairy Sci. 76:1589-1600.

Dado, R. G., and M. S. Allen. 1994. Variation in and relationships among feeding, chewing, and drinking variables for lactating dairy cows. J. Dairy Sci. 77:132-144.

Dechamps, P., B. Nicks, B. Canabt, M. Gielen, and L. Istasse. 1989. A note on resting behaviour of cows before and after calving in two different housing systems. Appl. Anim. Behav. Sci. 23:99-105.

DeVries, T. J., M. A. G. von Keyserlingk, D. M. Weary, and K. A Beauchemin. 2003a. Technical note: Validation of a system for monitoring feeding behavior of dairy cows. J. Dairy Sci. 86:3571-3574

DeVries, T. J., M. A. G. von Keyserlingk, D. M. Weary, and K. A. Beauchemin. 2003b. Measuring the feeding behavior of lactating dairy cows in early to peak lactation. J. Dairy Sci. 86:3354-3361.

Drackley, J. R. 1999. Biology of dairy cows during the transition period: The final frontier? J. Dairy Sci. 82:2259-2273.

Friggens, N. C., B. L. Nielsen, I. Kyriazakis, B. J. Tolkamp, and G. C. Emmans. 1998. Effects of feed composition and stage of lacta- tion on the short-term feeding behavior of dairy cows. J. Dairy Sci. 81:3268-3277.

Goff, J. P., and R. L. Horst. 1997. Physiological changes at parturition and their relationship to metabolic disorders. J. Dairy Sci. 80:1260-1268.

Grummer, R. R. 1995. Impact of changes in organic nutrient metabolism on feeding the transition dairy cow. J. Anim. Sci. 73:2820-2833.

Haley, D. B., J. Rushen, and A. M. de Passille. 2000. Behavioural indicators of cow comfort: activity and resting behaviour of dairy cows in two types of housing. Can. J. Anim. Sci. 80:257-263.

Konggaard, S. P. 1983. Feeding conditions in relation to welfare for dairy cows in loose-housing systems. Pages 272-280 in Farm Animal Housing and Welfare. S. H. Baxter, M. R. Baxter, and J. A. D. MacCormack, ed. Martinus Nijhoff, Dordrecht, The Netherlands.

Krohn, C. C., and L. Munksgaard. 1993. Behaviour of dairy cows kept in extensive (loose housing/pasture) or intensive (tie-stall) environments. II. Lying and lying-down behaviour. Appl. Anim. Behav. Sci. 37:1-16.

Ladewig, J., and D. Smidt. 1989. Behaviour, episodic secretion of cortisol, and adrenocortical reactivity in bulls subjected to tethering. Horm. Behav. 23:344-360.

Melin, M., H. Wiktorsson, and L. Norell. 2005. Analysis of feeding and drinking patterns of dairy cows in two cow traffic situations in automatic milking systems. J. Dairy Sci. 88:71-85.

Müller, C., J. Ladewig, H. H. Thielscher, and D. Smidt. 1989. Behavior and heart rate of heifers housed in tether stanchions without straw. Physiol. Behav. 46:751-754.

National Research Council. 2001. Nutrient Requirements of Dairy Cattle. 7th rev. ed. National Academy Press, Washington, DC.

Nielsen, B. L. 1999. On the interpretation of feeding behaviour measures and the use of feeding rate as an indicator of social restraint. Appl. Anim. Behav. 63:79-91.

Nocek, J. E. 1997. Bovine acidosis: Implications on laminitis. J. Dairy Sci. 80:1005-1026.

Olofsson, J. 1999. Competition for total mixed diets fed for ad libitum intake using one or four cows per feeding station. J. Dairy Sci. 82:69-79.

Osborne, V. R., K. E. Leslie, and B. W. McBride. 2002. Effect of supplementing glucose in drinking water on the energy and nitrogen status of the transition dairy cow. Can. J. Anim. Sci. 82:427-433.

Overton, M. W., W. M. Sischo, G. D. Temple, and D. A. Moore. 2002. Using time-lapse video photography to assess dairy cattle lying behavior in a free-stall barn. J. Dairy Sci. 85:2407-2413.

Tolkamp, B. J., D. J. Allcroft, E. J. Austin, B. L. Nielsen, and I. Kyriazakis. 1998. Satiety splits feeding behaviour into bouts. J. Theor. Biol. 194:235-250.

Tolkamp, B. J., D. P. N. Schweitzer, and I. Kyriazakis. 2000. The biologically relevant unit for the analysis of short-term feeding behavior of dairy cows. J. Dairy Sci. 83:2057-2068.

Tucker, C. B., and D. M. Weary. 2004. Bedding on geotextile mattresses: How much is needed to improve cow comfort? J. Dairy Sci. 87:2889-2895.

Yeates, M. P., B. J. Tolkamp, D. J. Allcroft, and I. Kyriazakis. 2001. The use of mixed distribution models to determine bout criteria for analysis of animal behaviour. J. Theor. Biol. 213:413-425. 